Article

\title{
Sustainable Practices in Furniture Design: A Literature Study on Customization, Biomimicry, Competitiveness, and Product Communication
}

\author{
Matthew S. Bumgardner ${ }^{1}$ and David L. Nicholls ${ }^{2, *}$ \\ 1 Research Forest Products Technologist, Northern Research Station, Delaware, OH 43015, USA; \\ matthewbumgardner@usda.gov \\ 2 Research Forest Products Technologist, Pacific Northwest Research Station, Juneau, AK 99801, USA \\ * Correspondence: david.1.lnicholls@usda.gov; Tel.: +1-907-738-2176
}

Received: 28 October 2020; Accepted: 24 November 2020; Published: 28 November 2020

\begin{abstract}
This research considers the ecosystem services associated with furniture, one of the leading types of secondary wood products manufactured internationally. We review and synthesize the literature surrounding the sustainable design, use, and disposition of wood furniture and related products in global markets. We consider emerging and innovative design strategies for wood (in biomimicry, for example) as well as topics that have been gaining traction in recent years (i.e., green supply chain management and eco/environmental labels and related market communications). An overarching theme is to consider how firm competitiveness can be influenced, or even enhanced, by green practices in design and associated communications with consumers. With a trend toward increasing customization in the secondary wood product marketplace, the role of design might be changing. However, design remains a critical product development function in modern markets, and designers are well-positioned to influence sustainable material utilization and improve furniture product use and lifespan.
\end{abstract}

Keywords: sustainable design; secondary wood products; furniture; green manufacturing; eco-labels; eco-design; biomimicry

\section{Introduction}

It has been stated that "the physical form or design of a product is an unquestioned determinant of its marketplace success" [1]. Others have stated that "design is creative, and creativeness is knowledge, fantasy, and imagination" [2]. Indeed, in the wood products literature, design has been shown to be a significant contributor to consumer evaluation of appearance-based products such as hardwood furniture [3,4]. It has also been argued that designers, as intermediaries in the supply chain of fashion-based products, play a key role in filtering what products and features consumers have to select from-in this role, they ultimately serve as gatekeepers of fashion [5]. Others have posited that design has become too aesthetic and commercial in its aim and that the concept of good design should be extended to the sustainable and practical functioning of products [6]. Olkowicz and Grzegorzewska [7] argued that furniture designers should be aware of the consequences of their work and consider environmental impacts, and this in turn could help the competitiveness of small family-owned Polish furniture manufacturers. However, in a study of Portuguese wood furniture companies, Vicente et al. [8] found that firms used design more as a product development tool rather than for reduction of environmental impacts.

A trend that has increased in the wood products industry, and one that gives consumers more product choices (including material use), is customization. While often touted as a strategy for higher 
cost producers to compete with lower cost imported products [9], customization models put consumers more directly in contact with manufacturers, in a sense "bypassing" the influence of designers and retail buyers. It has been argued, for example, that product strategies that bring consumers closer to manufacturers can be beneficial when attempting to introduce novel product concepts such as character-marked furniture, which might meet resistance from retail buyers who are uncertain about how unfamiliar product features might be received on their sales floors [10].

Even in an increasingly customized economy, many products are actually more semi-custom rather than completely made-to-order. An example could be a dining room table where consumers can choose the wood species, finish, and hardwood that will be applied to a given design [11]. In such semi-custom products, much of the design element has been inserted into the final product even though consumers can choose many of the product's features. Given trends toward increasing consumer involvement in design decisions, and increasing interest in the sustainability of product design, the role of design could be evolving in the wood product industry.

For example, Pedrazzoli et al. [12] take the semi-custom furniture concept one step further. They envision a mini-factory model in Europe, located directly in shopping malls or "behind a glass pane", where consumers can create their own designs that are manufactured with panels on-site into customized furniture through integrated design and manufacturing software. Designers would be involved in the set-up of predefined product portfolios. This model would enable both a competitive product (e.g., customized, short lead time) and sustainable process (e.g., close to the customer/short supply chain and low finished product inventory). Others have called for a "paradigm shift" for the U.S. furniture industry whereby designs that allow for rapid assembly of customized modular furniture play a key role in the transformation [13]. However, these authors also point out that such products will represent a change from classic North American designs that largely originated in Europe. For example, in a study describing the concept of a "co-creation design experience", Chang and Hsieh [14] describe a concept of corrugated cardboard building blocks that can be assembled into a variety of forms by the consumer within the design parameters established by the firm. The provided parameters help the consumers to avoid "design failures", while at the same time allowing for customized options.

The objective of this paper was to review and synthesize the literature related to product design in furniture and related products, with an emphasis on design as a source of competitive advantage in an increasingly customized economy. Emerging themes including green supply chains, biomimicry, and eco-labeling are addressed as they relate to product design in the industry. The review will elucidate the connections these themes have to product design, and by extension the role product design has in providing ecosystem services.

The connection between furniture products and ecosystem services may at first seem tentative. However, furniture products have been evolving for centuries, providing not only practical or functional services, but also aesthetic benefits and environmental opportunities. Historic furniture pieces that are well cared for have been sequestering forest carbon, sometimes for centuries (Figure 1). Other ecosystem services provided by furniture and related products can potentially include reduced $\mathrm{CO}_{2}$ emissions during production, product substitution when wood is used instead of non-wood products, and other provisions that sustainable forestry can provide such as income for landowners and clean water and nontimber products from managed forestland [15]. Further, wood furniture provides opportunities for recycling and re-purposing that many other materials may not offer. In today's manufacturing environment, challenges remain to be competitive while also having an eye on sustainability issues. Given that the products remain sound, durable wood products will function to sequester forest carbon that would otherwise be emitted to the atmosphere through normal decay, combustion, or other release. The ultimate question becomes one of, can sustainable design be leveraged for competitive advantage? 


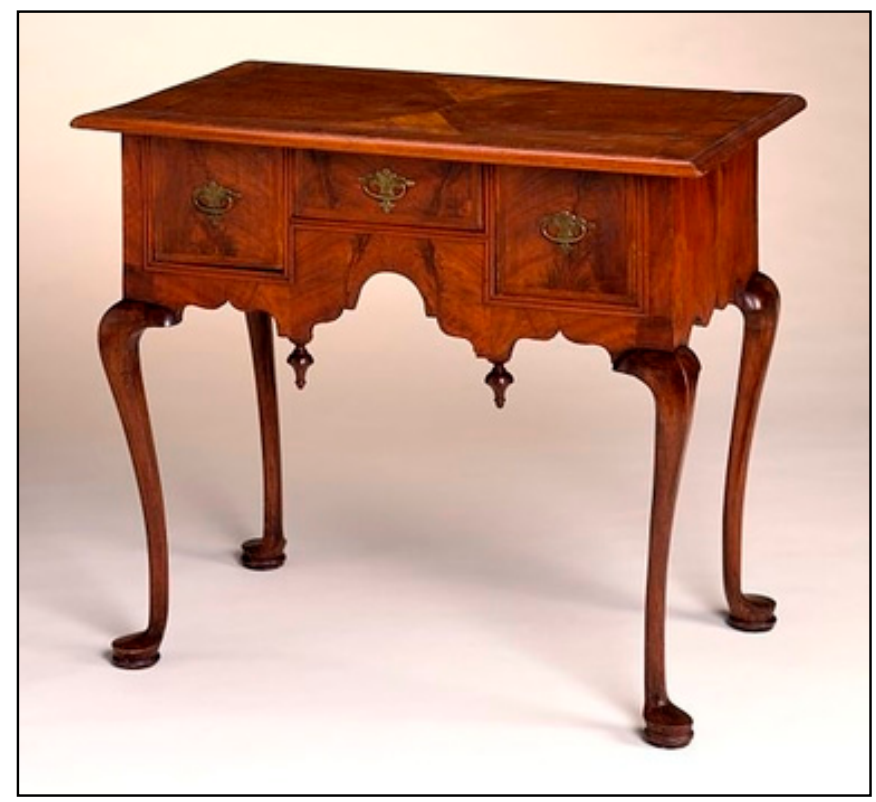

Figure 1. Furniture products have been sequestering carbon long before it was "cool" to do so. An example is this colonial era dressing table constructed in the mid-1700s. Wood products that are sufficiently dry and well preserved (and well designed) are capable of lasting centuries with essentially no change (photo source: https://study.com/academy/lesson/colonial-furniture-history-characteristics.html).

\section{Materials and Methods}

In this synthesis paper, we reviewed published literature regarding ecosystem services derived from furniture manufacture, emphasizing how sustainable design principles can be used to enhance product competitiveness. This topic included the specific themes of green manufacturing, green supply chains, eco-design, sustainable materials, biomimicry, and eco-labelling. While both "ecodesign" and "eco-design" are commonly found in the literature, "eco-design" is used in this synthesis for consistency; the same is also the case for "ecolabel" and "eco-label", with the latter being used in this article. The primary source of reviewed articles was a literature search carried out using Google Scholar in early 2020 based on the key words mentioned above. Other articles were identified based on cross-referencing with articles identified in the Google Scholar search or included based on the knowledge of the authors. Our scope was international and focused on peer-reviewed publications. To the best of the authors' knowledge, this paper is the first to offer an extensive review of ecosystem services provided through the design of furniture products.

A total of 81 articles were included in the synthesis, with 53 being published in 2010 or later years. Most papers were based on research conducted in North American, Europe, or Asia. While the synthesis did not consider a specific time frame, an emphasis was placed on more recent studies. The paper concludes with a discussion of future directions and challenges for secondary wood products firms regarding furniture design, customization, and the array of ecosystem services that could be provided therein.

\section{Results and Discussion}

\subsection{Green Manufacturing and Supply Chains}

Design is a fundamental aspect of green manufacturing and supply chains. Susanty et al. [16] found that eco-design had a positive impact on the environmental performance of small- and medium-sized wood furniture manufacturers in Indonesia. An extensive literature review by Tseng et al. [17] found that "design" was a major component of the word cloud developed from titles of scientific articles addressing green supply chain management. In addition, "design" was ranked fourth out of 50 words 
used to describe green supply chain practices [17]. In an extensive literature review of supply chain management across industries and countries, Ansari and Kant [18] reported that product design was found to be an important enabler of sustainable supply chain management in several studies. Separately, Ahi and Searcy [19] found in a similar review that product design was sometimes specifically mentioned in the definitions of green or sustainable supply chain management offered in the literature.

Product design decisions often have impacts on the supply chain in several ways, including selection of the materials used, the location of the suppliers of those materials, the product's life span, the ability to reuse/recycling/recover the product or its components, and how the product will be distributed and manufactured, to name a few [20,21]. Figure 2 shows a conceptual model of the traditional design process for furniture, as well as the stages added when incorporating eco-design. With eco-design included, product decisions are made with the product's end life in mind, and the resources needed to produce new products are also considered.

What are the most common eco-design principles for a product? According to a study of Dutch small to medium sized enterprises (defined in that study as 200 employees or fewer) [22], these principles include the following: use of recyclable materials, product durability and reliability, low energy consumption, ability to refurbish, less waste during production, clean production techniques, reduction of product weight, use of clean materials, and use of less and/or reusable packaging. Cordero et al. [23] claim that the benefits of eco-design include reducing environmental impacts, reducing company costs, developing innovative products, potential marketplace advantages, and enhancing a company's societal image.

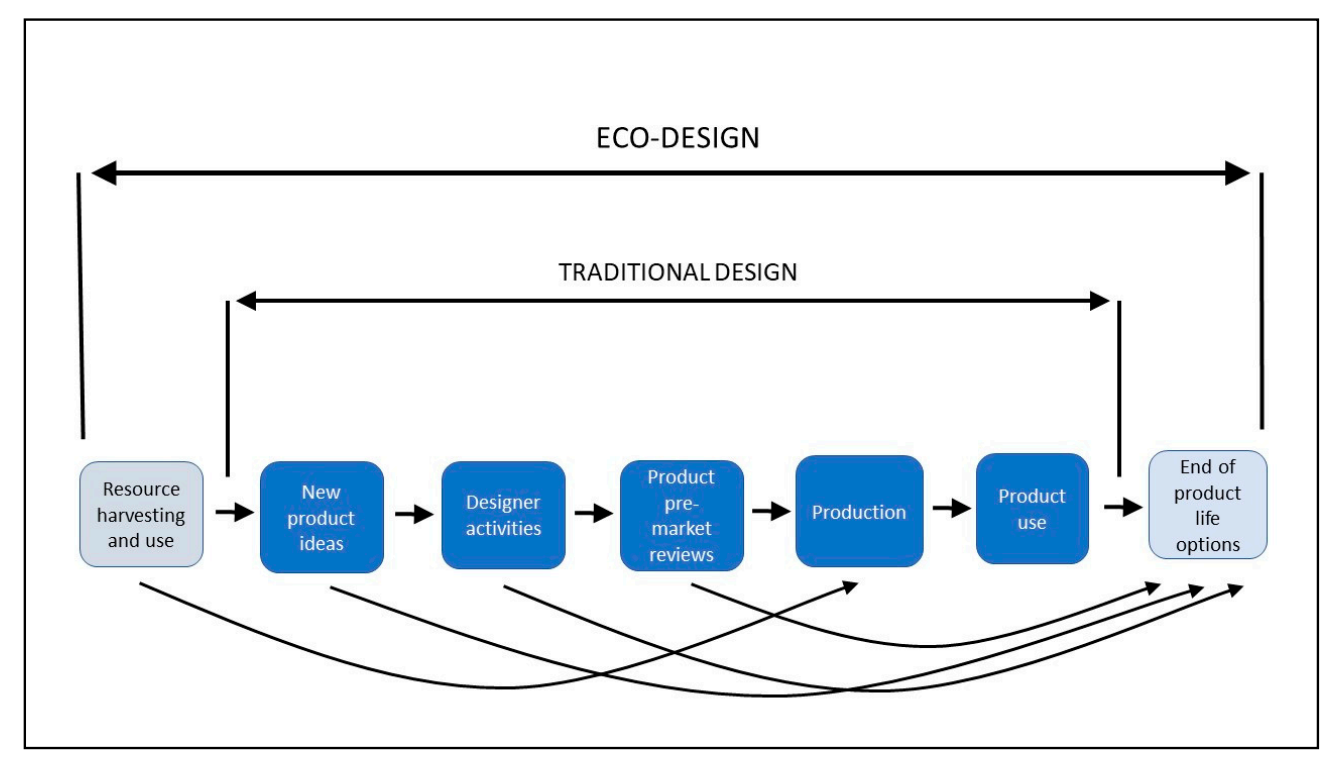

Figure 2. A conceptual model of traditional and eco-design processes for furniture product development (adapted from Knight and Jenkins [24]; Bumgardner et al. [25]).

Luttropp and Lagerstedt [2] propose "The Ten Golden Rules" of eco-design, which are generic and can be customized to specific situations. Paraphrased, they include the following: (1) avoid toxic substances or utilize closed loops for necessary ones; (2) minimize energy consumption in production and transport; (3) use structural features and high-quality materials to minimize weight; (4) minimize resource and energy consumption in product usage; (5) promote repair and upgrading; (6) promote long product life; (7) invest in better materials and surface treatments to protect products; (8) prearrange upgrading, repair, and recycling; (9) use materials that are recyclable; and (10) use as few joining elements as possible. Michelsen et al. [26] provided an interesting case study of how environmental performance could be measured through the extended supply chain (which included use and disposal) for various design models of an institutional chair; the associated differences in performance implied that design elements played an important role in sustainable furniture production and use. 


\subsection{Drivers of Sustainable Design in Furniture}

Green manufacturing practices have taken on increased importance in modern marketing. As noted by Handfield et al. [27], product design is an integral component of a shift in green furniture manufacturing away from simply reacting to regulations and toward meeting customer expectations. However, some studies have shown that compliance with regulations still was the single biggest driver of implementation of green manufacturing practices. This was the case across several industrial sectors in India; however, potential financial benefits, product positioning relative to competitors, and the perceptions of stakeholders and customers were also important considerations [28].

Klinpikul and Srichandr [29] found that, in the Thai furniture industry, eco-design was mostly driven by market and customer demand, and firms were responding to these market cues without necessarily knowing much about the principles of eco-design. Another study found that market-based factors, especially customer expectations and product design considerations, were the leading drivers of green manufacturing practices in the Malaysian wood furniture industry [30]. Cost reduction and differentiation in the market have also been shown to be objectives of sustainability programs [31]. Furthermore, Dangelico et al. [32] found that the integration of environmental sustainability issues into product design during the new product development process for upholstered furniture resulted in the opening of new markets and product arenas for implementing companies, but not necessarily improved financial performance. Olkowicz and Grzegorzewska [7] posit that even small, family-owned furniture firms with limited resources can be competitive on the global stage by focusing on their eco-design strategy. Overall, there appears to be a competitive aspect to implementing green design.

However, others have noted that eco-design has not delivered the competitive advantages envisioned by early researchers in the discipline [33]. This author claims that there is a "soft side" to eco-design that requires effective communication and coordination among functional units in an organization (e.g., engineering, design, manufacturing) for environmental product design to ultimately be successful. Such coordination is especially beneficial in the earliest stages of product development [33]. Knight and Jenkins [24] found similarly that numerous "pressures" in the product development process, across no less than 32 pieces of the overall product development "cake" [2], can collectively serve to impede the adoption of potential new eco-design tools.

In the U.S. wood furniture industry, Bumgardner et al. [25] found similar results regarding the development of character-marked furniture products. Such products had a greater chance for success when use of character-marked wood was committed to early in the process as part of the initial product concept by the product development team. Chances for success decreased when it was added as a consideration later in the process. Designers can be a key source of initial support for character-marks and other eco-design concepts if there is early coordination among functional units within the firm. However, as noted by Bumgardner et al. [10] in the United States, and Andersson and Koyumdzhieva [34] in Sweden, furniture companies differ in their product development processes, including the role designers typically play in the early stages of product idea conceptualization-in some companies, designers have more influence than in others.

\subsection{Potential Applications of Design to Green Supply Chains}

Related to several of the generic rules described above, Besch [35] posited that systems that promote reuse of office furniture products are superior to systems based on recycling systems or extending the longevity of the product. The reasons given were that, for recycling systems, the products must have simple design and component materials, otherwise recycling costs are too high; with long-lived products, firms might lose out on repeat purchases. Instead, Besch [35] developed a product-service system for office furniture in Germany whereby companies manufacture new furniture, rent furniture with maintenance and repair services provided as part of the contract, as well as remanufacture previously rented furniture once contracts expire. However, in the end, several barriers to the strategy were uncovered, including the importance of up-to-date furniture design and the associated role of changing fashion in many office settings. 
Prendeville [36], using in-depth case studies of several product development projects within a furniture firm in United Kingdom, concluded that eco-design strategy for the case company should focus on long-lived products with services (remanufacturing and reuse within a service model) rather than the use of recycled materials. However, the study stressed the design trade-offs within the model, and the importance of eco-design strategy aligning with the right business model. Another point regarding service and design involves focusing on the "front end" of the consumer purchase process. Gazo and Quesada [37] point out that the U.S. cabinet industry has remained competitive, in part because of the design services that integrate cabinet design into the whole kitchen; similarly, the U.S. wood office furniture industry increasingly provides whole-office organizational systems and solutions to complement the physical furniture product.

Consistent with calls for design to be more sustainable [6] and offering an opposing strategy to recycling or service models, other studies have investigated the potential to use design and green manufacturing principles in the "mass production" of heirloom furniture. Such furniture emotionally connects with consumers and thus realizes longer life spans [38]. In tracing the history of Su-style furniture in the Ming Dynasty, Fan and Feng [39] posit that traditional designs that are rooted in regional or local culture have inherent competitive advantages that could be leveraged with modern production techniques and marketing systems. According to the authors, these designs should maintain the stylistic, material, and quality characteristics that originally made them popular, while at the same time exhibiting design themes that appeal to modern consumers. The result would be furniture that connects culturally with consumers and thus realizes a long life span with the original purchasers.

Product and process design has been found to be a key component of sustainable business development in manufacturing and services [40]. These authors claim that $90 \%$ of production costs can be controlled by product design, through engagement of strategies such as design for manufacturing, design for quality, design for assembly, design for remanufacturing, design for packaging, design for recycling or reuse, and design for process control. Interestingly, Cordero et al. [23] similarly found that being "designer-driven" rather than "business-driven" (i.e., having a limited focus on factors such as production costs and time to market) was actually an impediment to the implementation of eco-design tools in many firms.

\subsection{Sustainable Materials for Furniture Design}

Product design has also been seen as important to promoting greater use of sustainable materials. It has been stated that "materials and their design are related and can be used to produce a sustainable product" [41]. Yuksel [42] posits that designers will play a critical role in encouraging the use of sustainable materials in the furniture industry of Turkey by introducing forms that are both functional and visually appealing to consumers. Wood is among several materials that can be selected for use in furniture products given the desired design parameters [43]. Even when using wood, it has been found that the species of wood itself carries implications for the consumers' perception of the final product [44]. On the other hand, Brinberg et al. [4] and Bumgardner et al. [3] found that design was an important attribute used by U.S. consumers when evaluating character-marked furniture products. This leads to the possibility that good design could "carry" character-marked or other wood materials, i.e., if consumers like the design, they might focus less on the specific attributes of the wood used.

In a review of the potential role of oil palm biocomposites (as opposed to solid wood) as raw materials for furniture manufacture in Malaysia, Suhaily et al. [41] discuss the importance of designers in not only encouraging specification of innovative materials, but also incorporating the materials in both an aesthetic and functional manner that helps the industry remain competitive. Mestre and Vogtlander [45] considered innovative seating systems made from cork oak in Portugal, using a design intervention approach combined with a life cycle assessment for new product development. The authors noted that designers often are surprised by the degree to which material selection matters to sustainability. Grzegorzewska and Więckowska [46] studied asymmetrical veneering in the furniture industry in Poland, which involves placement of a desirable species on the visual side of wood-based 
panels used in furniture, and a more utilitarian species on the non-visible side. Among their findings was the use of different veneer species on furniture panels should be specifically promoted as a design element of a diversified product in the marketplace to realize the market advantages. However, as with most elements of design, such potential aesthetic appeal had to be functionally feasible in the furniture manufacturing process as well.

\subsubsection{Biomimicry as a Furniture Design Concept}

Biomimicry is derived from the Greek words "bios" meaning life and "mimesis" meaning imitate. Many natural objects and materials are known to contain basic geometric principles that could be incorporated into manufactured products. As shown in Figure 3, geometric shapes and patterns can be used to aid furniture design using nature-based principles, creating new designs and new products [47]. The related concept of "evolutionary design" is a process in which the mutations of an object, material, shape, or structure lead to subsequent technology-assisted product development [48]. The result is a more refined product design at each stage or generation of development. Evolutionary design can be an important component of sustainable design for products as diverse as biomedical devices, toys, automotive products, and furniture.

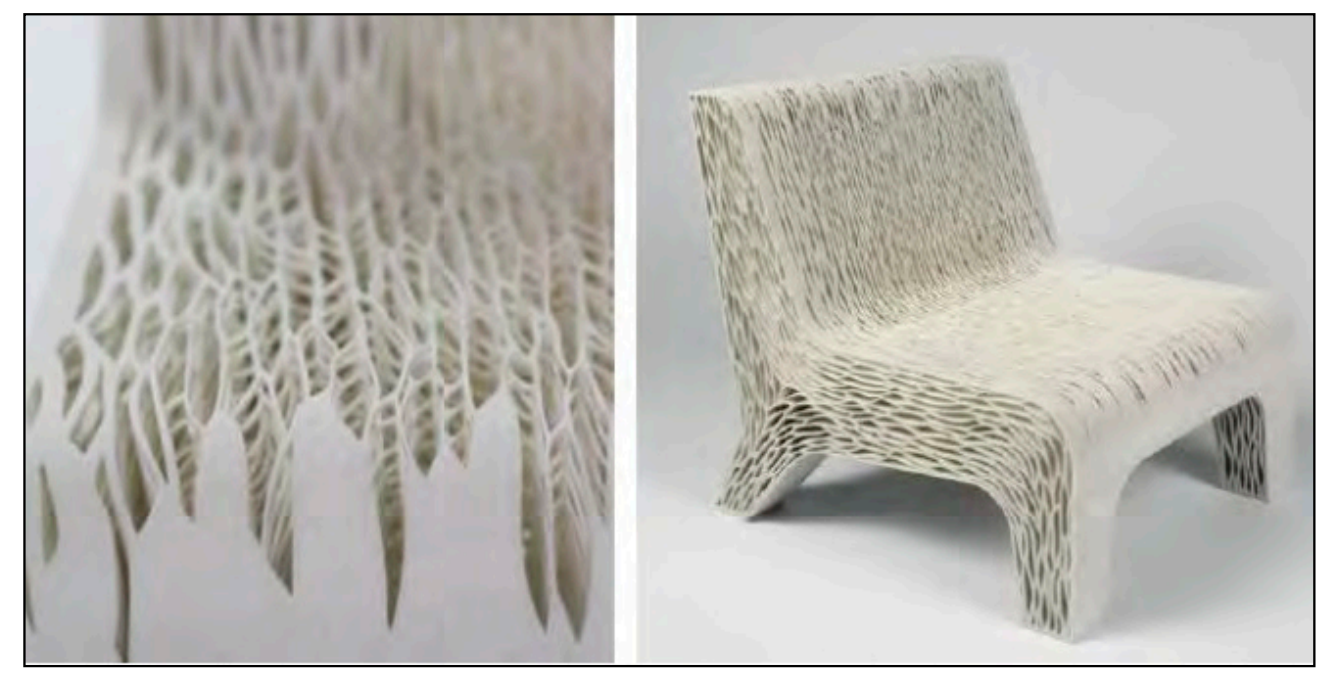

Figure 3. Biomimicry principles in chair design by Lilian Van Daal. The plant cell structure enhances not only the appearance, but also the structural attributes of the soft seat product (photo source: Lizoňová and Tončíková [47]).

Biomimicry can be considered a rising movement that stresses the derivation of "innovative and environmentally sound design from organic systems" [49]. Whether designers are creating new furniture, cars, medical devices, or buildings, biomimicry represents a new way of thinking that incorporates inspiration, development, and design [50]. Others have described nature as "a big factory, where faults are kept to a minimum", and biomimicry as nature's techniques, colors, proportions, and harmony in design [51]. Fisch [52] identifies biomimicry as a merging of nature and technology that incorporates elements of innovative and environmentally sound design from organic systems. On a broad level, biomimicry can be conceptualized over three levels when merging elements of biology, nature, and architecture into a single model [53]. These levels include the organism providing original inspiration, the behavior being mimicked, and the ecosystem being modeled. It is clear that biomimicry has no precise definition, but it can take many forms and interpretations.

\subsubsection{Biomimicry Applications in Furniture Design}

Formal research in biomimicry in furniture design is still evolving, but there are some studies that could guide future design work. Sayuti [54] used a mixed-methods empirical approach to classify 
235 furniture designs having embedded living organisms (such as plants, animals, and insects). Here, 4 main categories and 24 subcategories of design were considered. This research considered furniture design with living organisms (FDLO) in different contexts and types of functionality. Here, furniture designs not only were based upon features of living organisms, but also included them within the furniture piece (Figure 4). This research included interviews with furniture designers and broader feedback from a sample of more than 250 potential furniture users internationally on how they perceived furniture images. The objective was to evaluate emotional responses and preferences towards FDLOs, on the assumption that designs arousing emotions can generate deeper connections between users and designs. Several trends and generalizations regarding FDLOs were noted in this study:

1. Among living organisms, plants were usually preferred;

2. Among plants, green leafy plants were preferred to others, such as fungi or moss;

3. For furniture pieces, contemporary simple designs were preferred to more complicated antique designs;

4. Regarding materials, fabrics and wood were usually preferred over materials such as glass or acrylic.

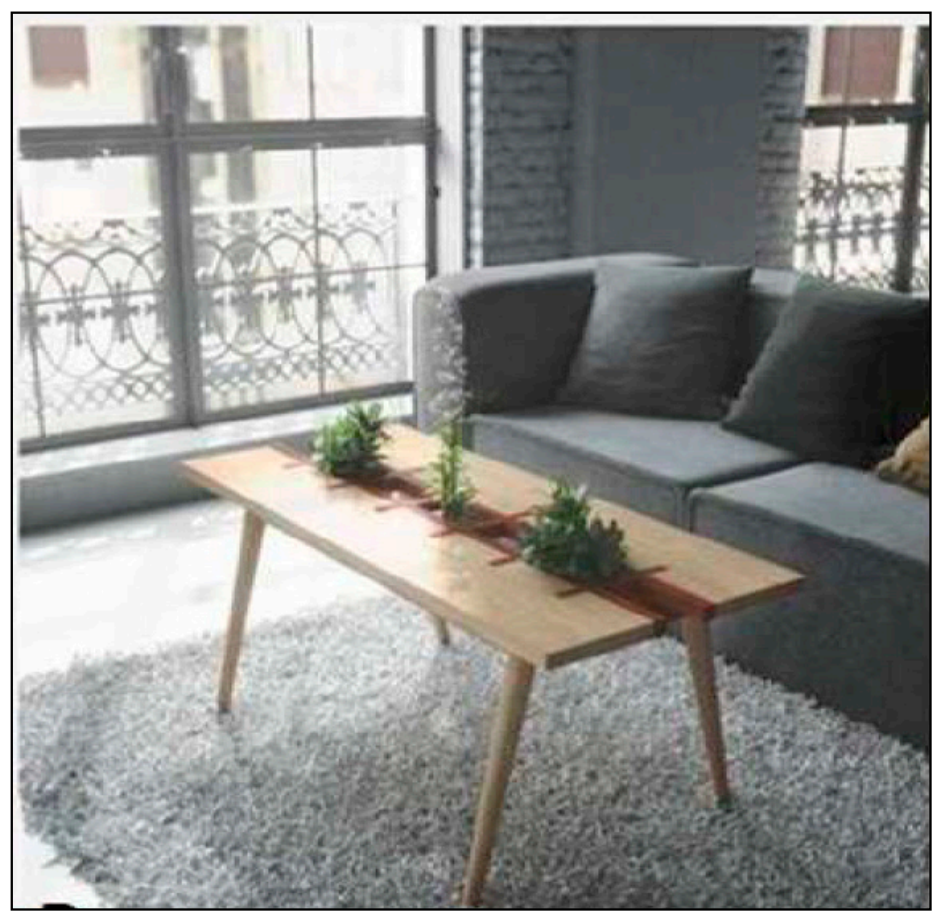

Figure 4. Biomimicry can include furniture embedded with living organisms, such as this table (the "Stitch Table" by Greg Zulkie) including a center strip of plants (photo source: Sayuti [54]).

Biomimicry can also refer to regenerative processes such as growing and producing furniture products from microbial-scale materials. Cellulose producing bacteria can, under the right conditions, self-organize in a nano-structured material that exhibits many textile-like properties. Faidi [55] evaluated the feasibility of bacterial cellulose as a possible raw material for furniture production. Although the production rate was found to be very slow, the advantages included recyclability, sustainability, biodegradability, and new end-use opportunities. These emerging examples from biomimicry research illustrate the potential of innovative approaches to designing furniture with biomaterials that have low environmental footprints while also having aesthetic appeal and the potential to better connect consumers with nature. 


\subsection{Design and Vertical Supply Chain Considerations}

Studies have examined how sustainability is implemented by large furniture manufacturers in their upstream supply chains. A key tool is "standard-driven greening", where design plays a critical role. Standard-driven tools involve specifications of product features or processes that reduce the consumption of energy and materials; suppliers are then left to meet the specifications with their own design considerations. Such tools appeared to be best suited to improvements in production processes and eco-efficiency. In contrast, "mentoring-driven greening" is based more on close relationships and direct interaction with suppliers [29]. This tool was seen to work best for reducing the environmental impact of the final product as the flexibility could lead to more radical innovations.

There are implications for wood products retailers, or downstream supply chains, related to green manufacturing as well. For example, Zutshi et al. [56] found that furniture retailers seek competitive advantage through implanting and communicating environmental initiatives. In their study of Australian furniture retailers, the initiatives were voluntary and carried out in response to stakeholders' interests in sustainability. Other studies have found that retail buyers used different cues to evaluate products than product development personnel in manufacturing firms, which creates challenges in the supply chain when manufacturers attempt to introduce new products [3,4].

\subsection{Marketing Sustainable Design—Can Green Communication Play a Role?}

It is difficult to underestimate the importance of design to products; this is especially true in the case of appearance-based wood products such as furniture and cabinets. The literature discusses the evaluation of design by consumers, with two basic schools of thought emerging on the cognitive processes involved. The cognitive processing involved in evaluating design can be holistic or atomistic. With holistic processing, objects are evaluated as a whole and not as a collection of separate attributes [57]. With atomistic processing, objects are evaluated as a collection of their individual attributes [58], and often it is possible to discern the most important attributes to consumers for a given product [59]. However, with sustainable design, which can involve unseen factors such as green supply chain management, consumers cannot use such information as part of their product evaluation without some kind of label or other communication. Others have stressed the importance of incorporating elements of the entire supply chain into eco-label design and new product development of green products [30]. Environmental impacts of production and consumption can be communicated through eco-labels or environmental labels. Bonsi et al. [60] and Iraldo et al. [61] point out the important differences between these two types of labels; for the purposes of this paper, both terms will be used to express green communication about products.

Product labelling first emerged in the 1970s primarily as a tool for consumer product safety [61], and later, eco-labelling grew to be a tool for certifying that products meet certain sustainability criteria. In 1993, the U.S. Environmental Protection Agency defined certification as an environmental label, or eco-label, used to communicate information to the consumer. An eco-label for wood furniture products dates several decades in the European Union (EU) and underwent a substantial revision between 2013 and 2016 [62]. The EU ecolabel for flooring and furniture is shown in Figure 5. However, it had been suggested that none of the eco-labelling classification methods seemed ideally suited to furniture products [63]. Eco-labelling and other certification schemes have been identified as tools for furniture manufacturers to increase consumer confidence while demonstrating leadership in sustainability practices [64]. There is some flexibility in how eco-labels are implemented because they can be issued by product manufacturers, trade associations, or independent third parties [65]. 


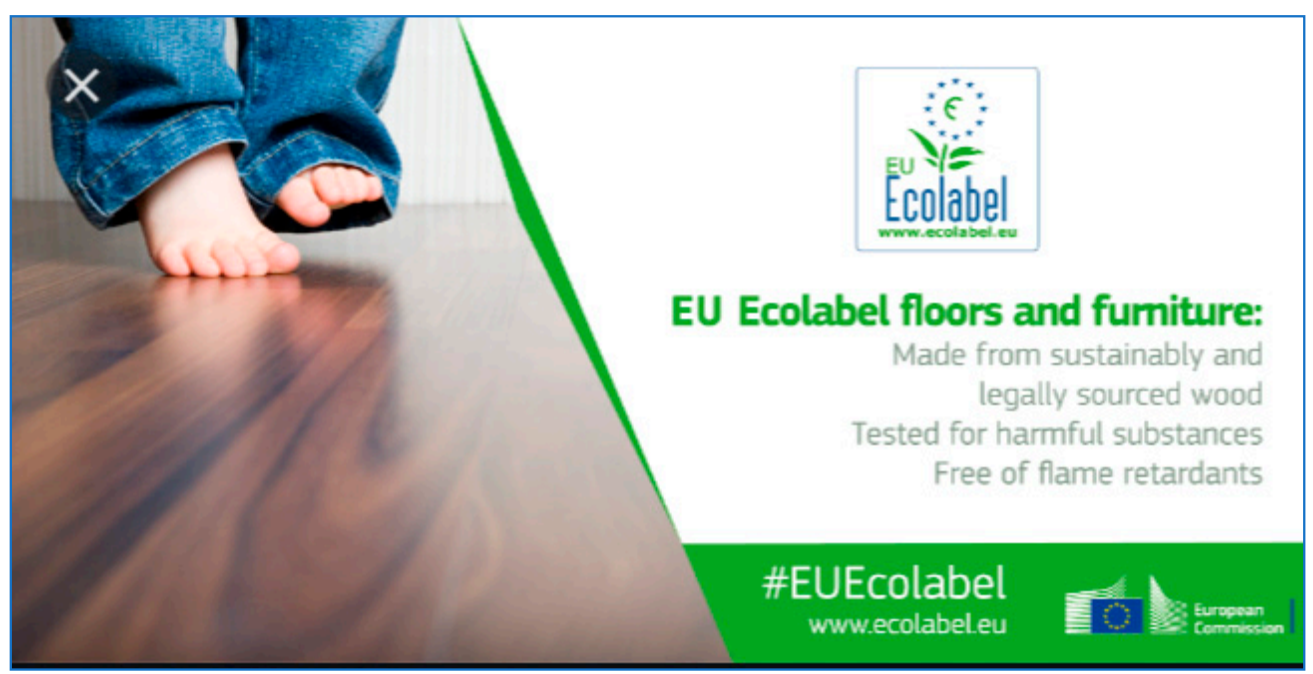

Figure 5. EU ecolabel for floors and furniture, providing product details and emotional connection to consumers (source: www.ecolabel.eu).

Iraldo et al. [61] identified several elements of effective eco-labelling programs. Such programs should promote the diffusion of product information so consumers can make more informed choices, and include the social aspects of products, including ethical gaurantees in the supply chain. This in turn could increase the market share of eco-labelled products and improve firm competitiveness. Ultimately, eco-label programs should help stimulate innovation in envrionmental performance and provide opportunities for small and medium-sized enterprises. Taufique et al. [66] considered eco-labels for general products (not restricted to furniture), identifying ten parameters that could enhance the effectiveness of eco-labels. These include consumer awareness, consumer knowledge, consumer involvement, consumer trust, design and visibility, credibility of the source, type and level of information, clarity of meaning, persuasiveness, and private benefits.

Similarly, several guidelines were recommended for eco-labelling programs for wood and paper products. Heikkonen [67] used a metaregression analysis to examine the factors influencing consumer willingness to pay and researched the literature to evaluated effective characteristics and information contained on eco-labels. Consumer willingness to pay for eco-labeled products was generally greater when labels provided more detailed information, including the name of the certifying agency, environmental benefits, and product comparison information. Environmental organizations (i.e., non-government entities) were perceived as being the most credible label providers. Wood and durable products could capture larger price premiums than less durable products such as paper. Regarding demographic factors, older consumers were generally more willing to pay for eco-labeled wood and paper products (versus younger consumers).

In cases where consumer acceptance of eco-labels has been limited, or slow to catch on, one theory is that the label criteria are too complex [68]. The EU eco-label scheme has adopted a criteria complexity index designed to measure label complexity, and the following measures were suggested: (1) use fewer materials in the product; (2) have shorter and less complex supply chains; (3) use solid wood instead of wood-based panels when possible; and (4) identify competent, well-informed suppliers [68]. A study of consumers of children's furniture in China similalry found that $83 \%$ of respondents preferred the use of solid wood in the product and preferred environmentally certified products and those with verified legal wood sourcing [69]. Others [70] have identified the need for certification standards to clearly communicate sustainability, security, and quality to consumers. In addition to these qualties, effective labels must provide a subjective emotional connection to potential customers.

Eco-labels can be used in tandem with eco-design strategies for furniture products. Green public procurement (GPP) can be seen as a promising method to promote environmentally sound product design and motivate manufacturers to make products with reduced environmental impacts [71]. 
Presently, the EU has developed an official eco-label for furniture products [72], certifying that wood, cork, and bamboo materials are legally sourced, sustainably managed, meet low formaldehyde emissions, and satisfy restricted use of hazardous substances or residues. Further, furniture consisting of multiple parts must be designed for ease of disassembly for reuse and recycling.

\section{Applications of Eco-Labeling to Sustainable Design-Are Consumers Willing to Pay?}

Two elements of eco-labeling programs are typical of many products, including the following: (1) they introduce an intangible attribute to a product, which requires a label or "stamp of approval" by some third party; and (2) they are generally expensive to administer [73]. Therefore, eco-labelling would be most effective if the willingness-to-pay price premium by consumers is greater than the expected costs. Programs should be carefully planned and the price premiums that consumers are willing to pay should be carefully evaluated.

Willingness to pay for eco-label and/or certified wood products has been an active area of research for several decades. However, there is an important distinction between consumer "purchase intention" when presented with hypothetical situations versus actual purchasing behavior. In other words, there is sometimes a disconnect between a consumer's stated purchase intention and actual willingness to pay a price premium. Tan et al. [74] found this to be the case for consumer preferences of flooring in China, even when consumers were familiar with a well-established eco-label. Still, willingness-to-pay research provides insights into consumers perceptions of eco-labeled furniture products, as discussed below.

Anderson and Hansen [75] evaluated consumer preferences for eco-labeled wood furniture (CD racks), and it was found that certified forest products' price premiums were most likely via market segmentation, but less likely in broader markets (i.e., big box stores). Veisten and Solberg [73] evaluated willingness to pay for certified wood furniture with European consumers, finding that relatively few consumers (15 percent of the British eco-segment and 5 percent of Norwegian eco-segment) were willing to pay a price premium for eco-labelled wood. In related work, Veisten [76] used contingent valuation combined with conjoint analysis methods to assess willingness to pay for eco-labelled wood furniture, finding price premiums ranging from 2 to 16 percent of the initial price. Mohamed and Ghani [77] evaluated consumer willingness to pay for household furniture in Malaysia, finding that most respondents (74 percent) preferred environmentally certified furniture when priced the same as non-certified furniture. However, a much lower percentage was willing to pay a price premium.

Cai and Aguilar [78] evaluated 19 studies internationally for willingness to pay for environmentally certified wood products, finding price premiums ranging from about 1 to 39 percent. They also found that higher price premiums often resulted from frequently purchased wood products and those with lower base prices. Wan et al. [79] studied willingness to pay for eco-friendly children's furniture in two cities in China and found that 53 percent of respondents would pay up to a 10 percent premium for such furniture, while 45 percent would pay greater than a 10 percent premium (just 2 percent reported they would pay no premium). Marital status, education level, environmental perceptions, and a healthy lifestyle orientation were also correlated with willingness to pay (WTP).

Willingness to pay for certified wood products within the supply chain has also been evaluated for secondary manufacturers [80]. In this sample of 121 Italian firms, price premiums for certified panels and boards ranged from 2.4 to 4.1 percent. However, less than 30 percent of respondents exhibited any willingness to pay at all.

\section{Conclusions}

There are several reasons why eco-design tools are not more widely used in industrial design; for example, they are perceived by many designers to be too cumbersome, complicated, and/or time-consuming given the numerous other requirements typical of a given design project [81]. Furthermore, sustainable design adds steps to the traditional design process for furniture through increased consideration of resource harvesting and use, as well as end of product life options (Figure 2). However, these additional steps in turn translate into ecosystems services being provided to consumers 
and society. A synthesis of the product design literature also shows that sustainable design can help competitiveness in several ways. In a more traditional sense, there is research suggesting that a business model focused on well-designed, emotionally appealing products contributes to the overall lifespan of higher-value furniture products. Longer functional lifespans have positive implications for disposal, carbon storage, and resource use. In the newer and evolving customization market, design plays an important consultative role in furniture production. Within customized production models, there are differences in the design function. At one end of the spectrum, designers work directly with end users on made-to-order products. This can serve to shorten and simplify supply chains while meeting consumer needs for personalized, non-commodity products. At the other end of the spectrum, designers can set broad design parameters that guide consumers through computerized programs that help them create desired modular product configurations. Such designs often have advantages in speed of production and minimal material use. Moving forward, it seems it might be less common that designers work exclusively within companies' internal product development processes, but instead also interact more directly with end-users.

Designers also potentially have much influence over sustainable design, especially when green considerations are committed to early in companies' product development processes. From the selection of materials used to the ability to recycle or refurbish components, design decisions will play an increasingly important role in green supply chains moving forward. In conjunction with eco-labelling, consumers can be presented with sustainability choices when making purchase decisions. Previous research suggests that consumers, based on intention, generally are willing to pay at least modest price premiums for green products. An area for future research would be to specifically assess the effectiveness of sustainable design messages in furniture and related products.

Another aspect of sustainable furniture design is understanding the drivers, whether they be more market-based or regulation-based. While regulations have been found to be the primary driver in many markets, the full creative potential of design is often associated with market-based demand. Perhaps the greatest function of product design remains the capturing of the imagination. New movements such as biomimicry provide additional opportunities for designers to engage consumers and draw interest to furniture products. Higher-value hardwoods add a fashion element to products, and this aesthetic appeal continues to be manifested in good furniture design. This review has shown that good design can enhance ecosystem services as well, while capturing both market and non-market values for consumers.

Author Contributions: M.S.B. and D.L.N. jointly conceived of this synthesis paper. M.S.B. primarily researched and wrote sections on green supply chains and sustainable design. D.L.N. primarily researched and wrote sections on biomimicry and eco/environmental labels. Both authors collaborated on locating key reference papers and contributing to the introductory and summary material. All authors have read and agreed to the published version of the manuscript.

Funding: This research received no external funding.

Acknowledgments: We thank two anonymous reviewers for their helpful comments on this manuscript.

Conflicts of Interest: The authors have no conflict of interest to report.

\section{References}

1. Bloch, P.H. Seeking the ideal form: Product design and consumer response. J. Mark. 1995, 59, 16-29. [CrossRef]

2. Luttropp, C.; Lagerstedt, J. Ecodesign and the ten golden rules: Generic advice for merging environmental aspects into product development. J. Clean. Prod. 2006, 14, 1396-1408. [CrossRef]

3. Bumgardner, M.; Nicholls, D.; Barber, V. Character-marked furniture made from red alder harvested in southeast Alaska: Product perspectives from consumers and retailers. Can. J. For. Res. 2009, 39, 2450-2459. [CrossRef]

4. Brinberg, D.; Bumgardner, M.; Daniloski, K. Understanding perception of wood household furniture: Application of a policy capturing approach. For. Prod. J. 2007, 57, 21-26. 
5. Solomon, M.R. Building up and breaking down: The impact of cultural sorting on symbolic consumption. Res. Consum. Behav. 1988, 3, 325-351.

6. Saval, N. How good design failed us. The New Yorker. 2019. Available online: https://www.newyorker.com/ culture/cultural-comment/how-good-design-failed-us (accessed on 10 April 2019).

7. Olkowicz, M.; Grzegorzewska, E. Eco-design as a strategic way to competitiveness in global markets for furniture family-owned MSMEs. J. Intercult. Manag. 2014, 6, 203-214. [CrossRef]

8. Vicente, J.; Frazao, R.; da Silva, F.M. Sustainable product design and the wood furniture sector. In Advances in Ergonomics in Design, Advances in Intelligent Systems and Computing; Rebelo, F., Soares, M., Eds.; Springer: Cham, Switzerland, 2018; Volume 588, pp. 762-772.

9. Nicholls, D.L.; Bumgardner, M.S. Challenges and opportunities for North American hardwood manufacturers to adopt customization strategies in an era of increased competition. Forests 2018, 9, 186. [CrossRef]

10. Bumgardner, M.; Bush, R.; West, C. Beyond yield improvement: Selected marketing aspects of charactermarked furniture. For. Prod. J. 2000, 50, 51-58.

11. Bumgardner, M.S.; Graham, G.W.; Goebel, P.C.; Romig, R.L. How clustering dynamics influence lumber utilization patterns in the Amish-based furniture industry in Ohio. J. For. 2011, 109, 74-81.

12. Pedrazzoli, P.; Cavadini, F.A.; Corti, D.; Barni, A.; Luvini, T. An innovative production paradigm to offer customized and sustainable wood furniture solutions exploiting the mini-factory concept. In Advances in Production Management Systems. Innovative and Knowledge-Based Production Management in a Global-Local World; Grabot, B., Vallespir, B., Gomes, S., Bouras, A., Kiritsis, D., Eds.; Springer: Berlin/Heidelberg, Germany, 2014; Volume 439, pp. 466-473. [CrossRef]

13. Schuler, A.; Buehlmann, U. Identifying Future Competitive Business Strategies for the U.S. Furniture Industry: Benchmarking and Paradigm Shifts; General Technical Report NE-304; USDA Forest Service, Northeastern Research Station: Newtown Square, PA, USA, 2003.

14. Chang, C.L.; Hsieh, M.H. Application of co-creation design experiences to the development of green furniture. In Human Interface and the Management of Information: Applications and Services; Yamamoto, S., Ed.; Lecture Notes in Computer Science; Springer International Publishing: Cham, Switzerland, 2016; Volume 9735, pp. 235-243. [CrossRef]

15. Baumgartner, R.J. Sustainable development goals and the forest sector-A complex relationship. Forests 2019, 10, 152. [CrossRef]

16. Susanty, A.; Santoso, H.; Sari, D.P.; Parasayu, S. Effect of internal green supply chain practices on environmental performance of SMEs of wooden furniture industry. Proc. World Congr. Eng. 2017, II, 599-604.

17. Tseng, M.-L.; Islam, M.S.; Karia, N.; Fauzi, F.A.; Afrin, S. A literature review on green supply chain management: Trends and future challenges. Resour. Conserv. Recycl. 2019, 141, 145-162. [CrossRef]

18. Ansari, Z.N.; Kant, R. A state-of-art literature review reflecting 15 years of focus on sustainable supply chain management. J. Clean. Prod. 2017, 142, 2524-2543. [CrossRef]

19. Ahi, P.; Searcy, C. A comparative literature analysis of definitions for green and sustainable supply chain management. J. Clean. Prod. 2013, 52, 329-341. [CrossRef]

20. Djunaidi, M.; Sholeh, M.A.A.; Mufiid, N.M. Analysis of green supply chain management application in Indonesian wood furniture industry. AIP Conf. Proc. 2018. [CrossRef]

21. De Paula Alvarenga, T.H.; Assumpção, J.J.; Sartori, S.; de Souza Campos, L.M.; Maldonado, M.U.; Forcellini, F.A. Green supply chain management and business process management: A union for sustainable process in a furniture factory. Asian J. Bus. Manag. Sci. 2015, 4, 1-13.

22. Van Hemel, C.; Cramer, J. Barriers and stimuli for ecodesign in SMEs. J. Clean. Prod. 2002, 10, 439-453. [CrossRef]

23. Cordero, P.; Poler, R.; Sanchis, R. Identification of the key sustainability issues to develop new decision support tools in the Spanish furniture sector. Int. J. Econ. Manag. Eng. 2010, 4, 1507-1519.

24. Knight, P.; Jenkins, J.O. Adopting and applying eco-design techniques: A practitioners perspective. J. Clean. Prod. 2009, 17, 549-558. [CrossRef]

25. Bumgardner, M.S.; Bush, R.J.; West, C.D. Product development in large furniture companies: A descriptive model with implications for character-marked products. Wood Fiber Sci. 2001, 33, 302-313.

26. Michelsen, O.; Fet, A.M.; Dahlsrud, A. Eco-efficiency in extended supply chains: A case study of furniture production. J. Environ. Manag. 2006, 79, 290-297. [CrossRef] [PubMed] 
27. Handfield, R.B.; Walton, S.V.; Seegers, L.K.; Melnyk, S.A. 'Green' value chain practices in the furniture industry. J. Oper. Manag. 1997, 15, 293-315. [CrossRef]

28. Govindan, K.; Diabat, A.; Shankar, M. Analyzing the drivers of green manufacturing with fuzzy approach. J. Clean. Prod. 2015, 96, 182-193. [CrossRef]

29. Klinpikul, N.; Srichandr, P. Status of eco-design in Thai furniture industry. Key Eng. Mater. 2010, 419-420, 769-772. [CrossRef]

30. Ratnasingam, J.; Wagner, K. Green manufacturing practices among wooden furniture manufacturers in Malaysia. Eur. J. Wood Wood Prod. 2009, 67, 485-486. [CrossRef]

31. De Marchi, V.; Di Maria, E.; Ponte, S. The greening of global value chains: Insights from the furniture industry. Compet. Chang. 2013, 17, 299-318. [CrossRef]

32. Dangelico, R.M.; Pontrandolfo, P.; Pujari, D. Developing sustainable new products in the textile and upholstered furniture industries: Role of external integrative capabilities. J. Prod. Innov. Manag. 2013, 30, 642-658. [CrossRef]

33. Boks, C. The soft side of ecodesign. J. Clean. Prod. 2006, 14, 1346-1356. [CrossRef]

34. Andersson, M.; Koyumdzhieva, T. Green Product Design: Aspects and Practices within the Furniture Industry. Master's Thesis, Jonkoping University, Jonkoping, Sweden, 2012.

35. Besch, K. Product-service systems for office furniture: Barriers and opportunities on the European market. J. Clean. Prod. 2005, 13, 1083-1094. [CrossRef]

36. Prendeville, S. Ecodesign and Material Selection for Eco-Innovation in Office Furniture Products. Ph.D. Thesis, Cardiff Metropolitan University, Cardiff, UK, 2015.

37. Gazo, R.; Quesada, H.J. A review of competitive strategies of furniture manufacturers. For. Prod. J. 2005, 55, 4-12.

38. Ingham, S. Furniture Longevity: How Mass-Produced Heirloom Furniture Supports Sustainable Consumption. Master's Thesis, Arizona State University, Tempe, AZ, USA, 2011.

39. Fan, K.-K.; Feng, T.-T. Discussion on sustainable development strategies of the traditional handicraft industry based on Su-style furniture in the Ming Dynasty. Sustainability 2019, 11, 2008. [CrossRef]

40. Gunasekaran, A.; Spalanzani, A. Sustainability of manufacturing and services: Investigations for research and applications. Int. J. Prod. Econ. 2012, 140, 35-47. [CrossRef]

41. Suhaily, S.S.; Jawaid, M.; Abdul Khalil, H.P.S.; Mohamed, A.R.; Ibrahim, F. A review of oil palm biocomposites for furniture design and applications: Potential and challenges. BioResources 2012, 7, 4400-4423.

42. Yuksel, E. Ecologic materials used in furniture design. Mugla J. Sci. Technol. 2016, 2, 125-130.

43. Namicev, P.; Tasevska, V. Specifications of eco-materials and their influence in the design of modern furniture. J. Process Manag. New Technol. Int. 2019, 7, 12-20. [CrossRef]

44. Bowe, S.; Bumgardner, M. Species selection in secondary wood products: Perspectives from different consumers. Wood Fiber Sci. 2004, 36, 319-328.

45. Mestre, A.; Vogtlander, J. Eco-efficient value creation of cork products: An LCA-based method for design intervention. J. Clean. Prod. 2013, 57, 101-114. [CrossRef]

46. Grzegorzewska, E.; Wieckowska, M. Market threats and opportunities in the implementation of sustainable products-Results from empirical study of furniture industry. Drewno 2017, 60, 111-123.

47. Lizoňová, D.; Tončíková, Z. Exploring the application of nature-inspired geometric principles when designing furniture and interior equipment. Acta Fac. Xylologiae Zvolen Publica Slovaca 2019, 61, 131-145.

48. Aversa, R.; Petrescu, R.V.V.; Petrescu, F.I.T.; Apicella, A. Biomimetic and evolutionary design driven innovation in sustainable products development. Am. J. Eng. Appl. Sci. 2016, 9, 1027-1036. [CrossRef]

49. Rusmadiah, A.; Rusman, M.S.; Kamaruzaman, M.F. The Potential of Biomimicry as an Influence for Local-Inspired Product Design. In Proceedings of the Art and Design International Conference (AnDIC 2016); Anwar, R., Mahamood, M., Md. Zain, D., Abd Aziz, M., Hassan, O., Abidin, S., Eds.; Springer: Singapore, 2018.

50. Omar, W.N.F.W.; Rahman, K.A.A.A. Development of conceptual framework of biomimicry thinking process. Int. J. Arts Sci. 2015, 8, 55-76.

51. Tavsan, F.; Sonmez, E. Biomimicry in furniture design. Procedia Soc. Behav. Sci. 2015, 197, $2285-2292$. [CrossRef]

52. Fisch, M. The nature of biomimicry: Toward a novel technological culture. Sci. Technol. Hum. Values 2017, 42, 795-821. [CrossRef]

53. Zari, M.P. Biomimetic approaches to architectural design for increased sustainability. In Proceedings of the International Conference on Sustainable Building, Seoul, Korea, 27-29 June 2007. 
54. Sayuti, N.A.A. Biophilic Design? A Study of Emotions, Influences, and Perceptions of Furniture Design Incorporating Living Organisms. Ph.D. Thesis, University of Canberra, Canberra, Australia, 2016.

55. Faidi, M. Feasibility of Bacterial Cellulose in Furniture Design. Bachelor's Thesis, Aalto University, Espoo, Finland, 2017.

56. Zutshi, A.; Creed, A.; Holmes, M.; Brain, J. Reflections of environmental management implementation in furniture. Int. J. Retail Distrib. Manag. 2016, 44, 840-859. [CrossRef]

57. Murray, D.J. Gestalt Psychology and the Cognitive Revolution; Harvester Wheatsheaf: New York, NY, USA, 1995.

58. Durgee, J.F. Product drama. J. Advert. Res. 1988, 28, 42-49.

59. Huthinson, J.W.; Alba, J.W. Ignoring irrelevant information: Determinants of consumer learning. J. Consum. Res. 1991, 18, 325-345. [CrossRef]

60. Bonsi, R.; Hammett, A.L.; Smith, B. Eco-labels and international trade: Problems and solutions. J. World Trade 2008, 42, 407-432.

61. Iraldo, F.; Griesshammer, R.; Kahlenborn, W. The future of ecolabels. Int. J. Life Cycle Assess. 2020, 25, 833-839. [CrossRef]

62. Donatello, S.; Moons, H.; Wolf, O. Revision of EU Ecolabel Criteria for Furniture Products; Final Technical Report; EUR 28443 EN; European Commission: Luxembourg, 2017; 126p.

63. Bärsch, J. The Feasibility of an EU Eco-Label for Furniture; German Federal Environmental Agency: Koln, Germany, 2001.

64. Osburg, V.-S.; Conroy, D.; Toporowski, W. Furnishing sustainable futures: An exploration of how furniture manufacturers can demonstrate sustainable leadership. In Proceedings of the 10th International Symposium on Sustainable Leadership, Dubrovnik, Croatia, 2-5 June 2015; Avery, G.C., Bouchet, M.-L., Eds.; Institute for Sustainable Leadership: Pymble, NSW, Australia, 2015; pp. 57-68.

65. Hrabovsky, E.E. Global Demand for Certified Hardwood Products as Determined from a Survey of Hardwood Exporters. Master's Thesis, West Virginia University, Morgantown, WV, USA, 2003.

66. Taufique, K.M.R.; Siwar, C.; Talib, B.; Sarah, F.H. Synthesis of constructs for modeling consumers' understanding and perception of eco-labels. Sustainability 2014, 6, 2176-2200. [CrossRef]

67. Heikkonen, H.-L. Developing Guidelines for an Ideal Eco-Label for Wood and Paper Products in the U.S. Master's Thesis, North Carolina State University, Raleigh, NC, USA, 2012.

68. Donatello, S.; Cordella, M.; Kaps, R.; Kowalska, M.; Wolf, O. Are the existing EU Ecolabel criteria for furniture products too complex? An analysis of complexity from a material and a supply chain perspective and suggestions for ways ahead. Int. J. Life Cycle Assess. 2020, 25, 868-882. [CrossRef]

69. Wan, M.; Chen, J.; Toppinen, A. Consumers' environmental perceptions of children's furniture in China. For. Prod. J. 2015, 65, 395-405. [CrossRef]

70. Savelli, E. Using environmental standards to communicate security, quality and eco-design in the furniture sector: An Italian case study. In Proceedings of the 7th International Conference on Mechanics and Materials in Design, Albufeira, Portugal, 11-15 June 2017.

71. Parikka-Alhola, K. Promoting environmentally sound furniture by green public procurement. Ecol. Econ. 2008, 68, 472-485. [CrossRef]

72. The EU Ecolabel for Furniture Products-"The official European label for Greener Products". Available online: https://ec.europa.eu/environment/ecolabel/documents/factsheet_furniture.pdf (accessed on 16 October 2020).

73. Veisten, K.; Solberg, B. Willingness to pay for certified wooden furniture: A market segment analysis. Wood Fiber Sci. 2004, 36, 40-55.

74. Tan, Q.; Imamura, K.; Nagasaka, K.; Inoue, M. Effects of eco-label knowledge on Chinese consumer preferences for certified wood flooring: A case study in Chongqing city. For. Prod. J. 2019, 69, 329-336.

75. Anderson, R.C.; Hansen, E.N. The impact of environmental certification on preferences for wood furniture: A conjoint analysis approach. For. Prod. J. 2004, 54, 42-50.

76. Veisten, K. Willingness to pay for eco-labelled wood furniture: Choice-based conjoint analysis versus open-ended contingent valuation. J. For. Econ. 2007, 13, 29-48. [CrossRef]

77. Mohamed, S.; Ghani, A.N.A. Malaysian consumers' preference and willingness to pay for environmentally certified wooden household furniture. Pertanika J. Trop. Agric. Sci. 2012, 35, 603-611.

78. Cai, Z.; Aguilar, F.X. Meta-analysis of consumer's willingness-to-pay premiums for certified wood products. J. For. Econ. 2013, 19, 15-31. [CrossRef] 
79. Wan, M.; Zhang, Y.; Ye, W. Consumer willingness-to-pay a price premium for eco-friendly children's furniture in Shanghai and Shenzhen, China. For. Prod. J. 2018, 68, 317-327.

80. Paletto, A.; Notaro, S. Secondary wood manufactures' willingness-to-pay for certified wood products in Italy. For. Policy Econ. 2018, 92, 65-72. [CrossRef]

81. Lofthouse, V. Ecodesign tools for designers: Defining the requirements. J. Clean. Prod. 2006, 14, $1386-1395$. [CrossRef]

Publisher's Note: MDPI stays neutral with regard to jurisdictional claims in published maps and institutional affiliations.

(C) 2020 by the authors. Licensee MDPI, Basel, Switzerland. This article is an open access article distributed under the terms and conditions of the Creative Commons Attribution (CC BY) license (http://creativecommons.org/licenses/by/4.0/). 